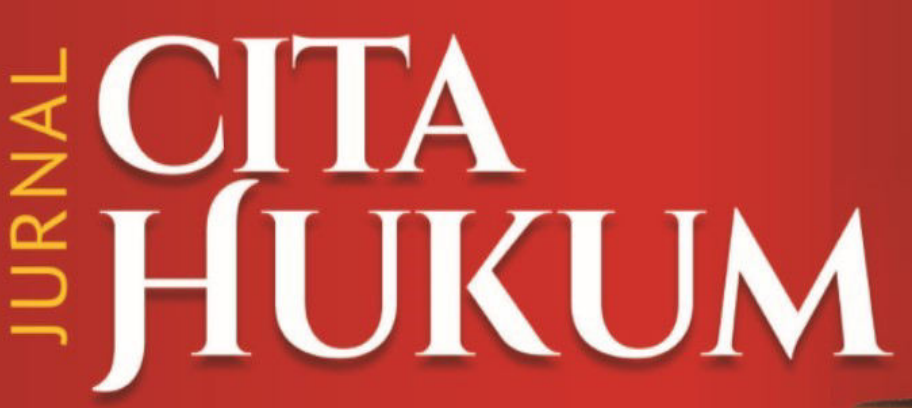

Indonesian Law Journal

- Analysis of the Nature of the Fulfillment of the Obligation in Iran and in France Civil Codes

Zahra Babajani, Saeid Kheradmandy \& Mohamad Javad Jafari. (Islamic Republic of Iran)

- Case Study of The Supreme Court Ruling Number: 3002 K/Pdt/2015 On The Validity of Provision of Income Agreement Which Was Made Before Divorce Based On Civil Code

Hazar Kusmayanti, Tri Utami Warapsari \& Linda Rachmainy. (Bandung, Indonesia)

- Malice in Crimes in Iran and The English Criminal Law

Peyman Rostamian, Mohammad Hossein Hajjarian, \& Hassan Ali Moazzanzadegan. (United Arab Emirates (UAE))

- Legislative Construction of the Post Amendment In Restoring Indonesian Democracy Asep Syarifuddin Hidayat. (Jakarta, Indonesia)

- The Implementation of Supreme Court Regulation Number 2 of 2012 concerning Limitation Adjustment of Mild Criminal Offenses and Amount of Fines in the Criminal Code Towards Handling of Minor Crime Cases

Abbas Sofwan Matlail Fajar \& Mara Sutan Rambe. (Islamic Republic of Pakistan)

- Legalizing Unofficial Marriage for Indonesian Migrant Workers In Malaysia

Afwan Faizin, Alfitra \& Ali Mansur. (Jakarta, Indonesia)

- Emancipation and Legal Justice; Portrait of Women's Legal Protection In Indonesia

Mentari Berliana Kemala Dewi \& Ridwan Arifin. (Semarang, Indonesia)

- The Role of Law on the Implementation of Green Banking in Indonesia Ria Safitri, Hartiwiningsih \& Hari Purwadi. (Surakarta, Indonesia)

- Роль спецслужб в ликвидации неповиновения (мятежных действий) в Индонезии и Филиппинах (Role of Secret Agent Institutions in Eradication of Rebels In Indonesia and Philippines)

Sekar Hapsari \& Saddam Aljihad. (Kazan, Federasi Russia) 


\section{VOLUME 7 NUMBER 1 (2019)}

JURNAL CITA HUKUM is Indonesian Law Journal published by Faculty of Sharia and Law, State Islamic University Syarif Hidayatullah Jakarta in Associate with Center for Study of Indonesian Constitution and Legislation (POSKO-LEGNAS) UIN Jakarta.

This journal specializes in Legal Studies and try to present various results of the latest and high-quality scientific research.

As an International Journal, all articles must be written in English or Russian, because they will be read online by millions of readers, both speakers of English and Russian.

JURNAL CITA HUKUM has been indexed at Web of Science (WOS) Web of Science (WOS) or Emerging Source Citation Index (ESCI) Clarivate Analytics, DOAJ, EBSCO, DIMENSION, Microsoft Academic Search, and SINTA 3 and become a CrossRef Member since year 2015. Therefore, all articles published by JURNAL CITA HUKUM will have unique DOI number.

\section{INTERNATIONAL EDITORIAL BOARD}

Prof. Carolyn Sappideen, Scopus ID: 6506771331 School of Law Western Sydney University, Australia

Prof. Alexander Fedorovich Malyy, Scopus Id: 57194874834 , Department of Constitutional Law, Kazan Federal University, Russian Federation

Prof. Razeen Sappideen, Scopus ID: 14041008300 School of Law Western Sydney University, Australia

Prof. Stanislav Shkel, Scopus Id: 56747984200, Department of Constitutional Law, Ufa State Petroleum Technological University, Russian Federation

Prof. Stefan Koos, Bundeswehr University Munich

Prof. Muhammad Munir, Scopus ID: 54414595100, Department of Law, International Islamic University Islamabad, Pakistan

Prof. Euis Nurlaelawati, Scopus ID: 56247081700, Faculty of Sharia and Law, State Islamic University (UIN) Sunan Kalijaga Yogyakarta

Prof Abdul Gani Abdullah, Universitas Islam Negeri Syarif Hidayatullah Jakarta

Prof. Salman Maggalatung, Center for the Study of Constitution and National Legislation (POSKOLEGNAS), Indonesia

Assoc. Prof. Asep Saepudin Jahar, Scopus ID: 57156653300 , Department of Economic Law Universitas Islam Negeri Syarif Hidayatullah Jakarta

Assoc. Prof. Ahmad Tholabi Kharlie, Thomson Reuters Id: R-5028-2017, Department of Family Law, Faculty of Sharia and Law, Universitas Islam Negeri Syarif Hidayatullah Jakarta

\section{EDITOR IN CHIEF}

Nur Rohim Yunus, Thomson Reuters Researcher ID: F-3477-2017, ORCID ID: 0000-0003-27821266, SSRN ID: 2645355, SINTA ID: 5975443, Department of Constitutional Law, UIN Syarif Hidayatullah Jakarta, Indonesia

\section{MANAGING EDITOR}

Muhammad Ishar Helmi, Thomson Reuters Researcher ID: F-3345-2017, ORCID ID: 0000-0001-7060-8191, SINTA ID: 6199804, Department of Criminal Law UIN Syarif Hidayatullah Jakarta, Indonesia.

\section{EDITORS}

Indra Rahmatullah, ORCID ID: 0000-0002-6160-4225, SINTA ID: 6200500, Department of Economic Law, Faculty of Sharia and Law, UIN Syarif Hidayatullah Jakarta, Indonesia

Fitria Fitria, ORCID ID: 0000-0001-9733-1233, Department of International Law, York Law School, University of York, UK, United Kingdom.

Mara Sutan Rambe, ORCID ID: 0000-0001-5404-6635, SINTA ID: 6200494, Department Criminal Law, Faculty of Law, UIN Syarif Hidayatullah Jakarta, Indonesia. Erwin Hikmatiar, Thomson Reuters Researcher ID: F-3235-2017, ORCID ID: 0000-0003-4103-818X, SINTA ID: 6200141, Center for The Study of Constitution and National Legislation (POSKOLEGNAS), UIN Jakarta.

Arip Purkon, ORCID ID: 0000-0002-6195-9384, Department of Law, University of Malaya, Malaysia.

\section{LANGUAGE EDITOR (ENGLISH AND RUSSIA)}

Raisa Shahrestani, Belgorodsky State University, Russia.

Firsty Izzata Bella, State Islamic University (UIN) Syarif Hidayatullah Jakarta, Indonesia.

\section{ASSISTANT TO THE EDITORS}

Anisaul Kamilah. State Islamic University (UIN) Syarif Hidayatullah Jakarta, Indonesia.

Firda Zahra, State Islamic University (UIN) Syarif Hidayatullah Jakarta, Indonesia.

Redaktur Office

Faculty of Sharia and Law UIN Syarif Hidayatullah Jakarta

Street Ir. H. Juanda 95 Ciputat Jakarta 15412

Phone. (62-21) 74711537, Faks. (62-21) 7491821

Website: www.fsh-uinjkt.net, E-mail: jurnal.citahukum@uinjkt.ac.id.

Link: http://journal.uinjkt.ac.id/index.php/citahukum 


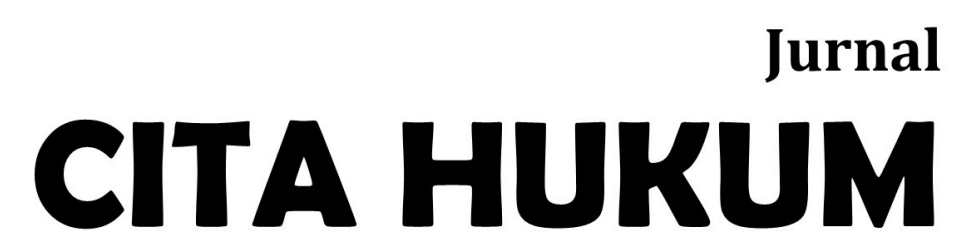

INDONESIAN LAW JOURNAL

Welcoming contributions from scientists, scholars, professionals, and researchers in the legal disciplines to be published and disseminated after going through script selection mechanisms, reviewing sustainable partners, and rigorous editing processes. 


\section{TABLE OF CONTENTS}

Analysis of the Nature of the Fulfillment of the Obligation in Iran

and in France Civil Codes

Zahra Babajani, Saeid Kheradmandy, Mohamad Javad Jafari

Case Study of The Supreme Court Ruling Number: 3002 K/Pdt/2015 On the Validity of Provision of Income Agreement Which Was Made Before Divorce Based on Civil Code Hazar Kusmayanti, Tri Utami Warapsari, Linda Rachmainy....

Malice in Crimes in Iran and The English Criminal Law

Peyman Rostamian, Mohammad Hossein Hajjarian, Hassan Ali Moazzanzadegan $.37-50$

Legislative Construction of the Post Amendment in Restoring Indonesian Democracy

Asep Syarifuddin Hidayat. $51-66$

The Implementation of Supreme Court Regulation Number 2 of 2012 concerning Limitation Adjustment of Mild Criminal Offenses and Amount of Fines in the Criminal Code Towards Handling of Minor Crime Cases

Abbas Sofwan Matlail Fajar, Mara Sutan Rambe. $.67-84$

Legalizing Unofficial Marriage for Indonesian Migrant Workers in Malaysia Afwan Faizin, Alfitra, Ali Mansur.

Emancipation and Legal Justice; Portrait of Women's Legal Protection in Indonesia Mentari Berliana Kemala Dewi, Ridwan Arifin.

The Role of Law on the Implementation of Green Banking in Indonesia

Ria Safitri, Hartiwiningsih, Hari Purwadi.... $115-138$

Роль Спецслужб В устранении Неповиновения или Мятежных Действий В Индонезии И Фидиппинах (Role of Secret Agent Institutions in Eradication of Rebels In Indonesia and Philippines)

Sekar Hapsari, Respiratori Saddam Aljihad. $.139-156$ 
JURNAL CITA HUKUM (Indonesian Law Journal)

FSH UIN Syarif Hidayatullah Jakarta

Vol. 7 No. 1 (2019), pp.115-138, DOI: 10.15408/jch.v7i1.10897

\title{
The Role of Law on the Implementation of Green Banking in Indonesia*
}

\author{
Ria Safitri, ${ }^{1}$ Hartiwiningsih, ${ }^{2}$ Hari Purwadi ${ }^{3}$ \\ Doctoral Program of Law, Universitas Sebelas Maret Surakarta, Indonesia
}

do: $\underline{10.15408 / \text { ich.v7i1.10897 }}$

\begin{abstract}
:
The Economic development in Indonesia shows significant results, yet it has a negative impact towards the environment. The trouble is that if the bank has provided credit or financing to customers, it turns out that the credit recipient company discharges waste into the river or other actions that undermine the environment. Do banks have helped in financing environmental damage? Then how was the bank's responsibility for credit channeled to polling debtors? Economic development cannot be separated from bank institutions as an intermediary institution which has become one of the drivers of the economy and business so that it has a strategic role that can be used to achieve certain goals. One of the objectives of development is environmental sustainability. In order to espouse environmental preservation, the pattern of green banking can be applied, but only a small number of conventional banks and Islamic banks implement it in credit assessment terms. The pattern of green banking practice that can be realized in each credit agreement and financing at the bank, among others: administrative patterns, associative patterns, incentive patterns and evaluative patterns. Those patterns can be implemented with great awareness and responsibility from all banks in Indonesia.
\end{abstract}

Keywords: law, bank, green banking

How to cite (turabian):

Safitri, Ria; Hartiwiningsih; Purwadi, Hari. "The Role of Law on the Implementation of Green Banking in Indonesia," Jurnal Cita Hukum [Online], Volume 7 Number 1 (20 March 2019).

${ }^{*}$ Received: Dec 5, 2018, revised: January 12, 2019, Accepted: February 22, 2019, Published: March 20, 2019.

${ }^{1}$ Ria Safitri is Law Doctoral Program Student, Sebelas Maret University, Surakarta, Indonesia.

2 Hartiwiningsih is Professor of Law, Sebelas Maret University, Surakarta, Indonesia.

${ }^{3}$ Hari Purwadi is Professor of Law, Sebelas Maret University, Surakarta, Indonesia.

*Corresponding Author: riasafitri@uinjkt.ac.id. 
Ria Safitri, Hartiwiningsih, Hari Purwadi

\title{
Peranan Hukum Dalam Pelaksanaan \\ Green Banking Di Indonesia.
}

\begin{abstract}
Abstrak:
Pembangunan ekonomi di Indonesia menunjukkan hasil yang cukup signifikan, akan tetapi menghasilkan dampak buruk terhadap lingkungan hidup. Permasalahannya yaitu apabila bank sudah menyalurkan kredit atau pembiayaan kepada nasabah yang ternyata perusahaan penerima kredit melakukan pembuangan limbah ke sungai atau kegiatan lainnya yang merusak lingkungan. Apakah bank dapat dikatakan turut membiayai terjadinya kerusakan lingkungan? Lalu bagaimana tanggungjawab bank terhadap kredit yang disalurkan pada debitur pencemar? Pembangunan ekonomi tidak dapat dilepaskan dari lembaga bank sebagai intermediary institution yang merupakan salah satu penggerak ekonomi dan bisnis sehingga memiliki peran strategis yang dapat digunakan untuk mencapai tujuan tertentu. Salah satu tujuan pembangunan adalah kelestarian lingkungan hidup. Dalam rangka menunjang pelestarian lingkungan hidup, pola green banking dapat diterapkan, akan tetapi hanya sebagian kecil bank konvensional dan bank syariah yang melaksanakannya dalam syarat penilaian kredit. Pola pelaksanaan green banking yang dapat direalisasikan dalam setiap perjanjian kredit dan pembiayaan pada bank, antara lain: pola administratif, pola asosiatif, pola pola insentif dan pola evaluatif. Pola demikian dapat dilaksanakan dengan kesadaran dan tanggungjawab yang besar dari semua bank di Indonesia.
\end{abstract}

Kata Kunci: Hukum, Bank, Green Banking

\section{Роль Закона о Внедрении Зеленого банкинга в Индонезии}

\begin{abstract}
Аннотация:
Экономическое развитие в Индонезии показывает значительные результаты, но оказывает негативное влияние на окружающую среду. Проблема в том, что, если банк предоставил кредит или фринансирование клиентам, выясняется, что компания-получатель кредита сбрасывает отходы в реку или другие действия, которые подрывают окружающую среду. Помогли ли банки в финансировании ущерба окружающей среде? Тогда как ответственность банка за кредит перешла к должникам? Экономическое развитие не может быть отделено от банковских учреждений как посредническое учреждение, которое стало одним из двигателей экономики и бизнеса, так что оно играет стратегическую роль, которая может быть использована для достижения определенных целей. Одной из целей развития является экологическая устойчивость. Чтобы поддержать сохранение окружающей среды, может быть применена схема «зеленого» банковского дела, но только небольшое количество обычных банков и исламских банков применяют ее $c$ точки зрения оценки кредитоспособности. Модель практики зеленого банковского дела, которая может быть реализована в каждом кредитном соглашении и финансировании в банке, среди прочего: административнье модели, ассоциативные модели, модели стимулирования и модели оценки. Эти модели могут быть реализованы с большой осведомленностью и ответственностью всех банков в Индонезии.
\end{abstract}

Ключевые слова: закон, банк, зеленый банкинг 


\section{Introduction}

National development that has been carried out is a continuous development effort in order to realize a just and prosperous society in accordance with Pancasila and Indonesian's Constitutional of 1945. To obtain this goal, the implementation of development must always pay attention to harmony, conformity and balance of various elements of development including in the economic, financial and the environment.

Indonesia is currently a country that is actively exploring natural resources as development capital for people's welfare. In fact, it is actually becoming a threat to people's welfare. As a result of environmental exploration, exploitation and tourism activities are increasingly being neglected and threatened. It can be seen how each region extracts all potential in its area without noticing to the principle of justice between generations and does not take into account for future needs. For instance, Kalimantan Island suffered significant forest damage, which caused flash floods and burden people. The Bali Island exploits tourism potential without feeling that the development of supporting tourism such as hotels, villas, opening new roads makes it easier for investors to damage the sustainability and authenticity of Bali.

The environmental crisis is a huge challenge of development, specifically in developing countries like Indonesia. Development activities whose purpose are to improve human welfare not only produce benefits but often also have negative impacts on the environment. The impact that is felt because of environmental damage is global warming, in almost all parts of the world can feel the impact like extreme weather. This condition is caused by past development activities that have not considered environmental issues. Supervision in development is an essential thing that must exist in policies and regulations such as the Environmental Law, in order to achieve environmental sustainability.

On the other hand, the current national economic development shows an increasingly integrated directly with the regional and global economy that can support national economic growth or can also harm the national economy. It can be said that economic development in Indonesia will face more complex challenges, thus requiring complex reactions and actions so that Indonesia can take a favorable side. One of the most important things is to adjust policies in the economic sector including the banking sector so that it is expected an ability to anticipate various challenges to strengthen the national economy amid global competition. 
However, in subsequent developments, economic globalization penetrated the field of law as a logical consequence of relations that occur between countries and between fields, where law functions as a regulator of relations. Law as an important reality in society is the most dominant aspect implicated by globalization. Changes in law include changes in ways of thinking, lifestyle behaviors that are in accordance with the demands of the times. Then the agenda of legal reform in the face of globalization includes Institutional reform, Instrumental reform, and Culture reform (Manan, 2005: 60).

Global linkages and various changes that occur have affected the legal system and direction of Indonesian legal politics. The Republic of Indonesia's Government System must be integrated with the system of other sectors, in order to support the wheels of government in achieving the country's goals. Therefore the law plays an important role in the effort to place Indonesia's position in global without disregarding guarantees and protection for the life of a just, affluent and prosperous society so that globalization provides tangible benefits to the life of the nation.

Another understanding related to globalization is the adjustment of a country's law to international law which is usually becoming an impact of the global economy. These adjustments are sometimes felt by developing countries as pressure from developed countries through international organizations and world bodies which in fact are shaped by developed countries. Indonesia underwent a pressure process from IMF, World Bank and others which forced Indonesia to adjust policies made based on the "direction" of world institutions. Even the international institutions can impose their desire on other countries, for example, those who are considered to violate human rights with the threat of not giving economic assistance, or political issues such as the government not implementing democracy are always associated with trade economic problems.

Those conditions force many countries such as Indonesia to adjust to the global legal system which incidentally comes from western countries. The usual adjustment process is done by ratifying international agreements so that they can become laws and apply in certain countries. Similarly, in the banking sector which has a strategic role in international business, it can even be said to have a very important role in trade and financial traffic.

One of the important things to be discussed in economic activities related to law is the banking area. The bank is one of the drivers of the economy and business, so it has a strategic role that can be used to reach certain purposes. The actual pattern of green banking has long been recommended by people who are concerned about environmental preservation, but only a small number of 
conventional banks and Islamic banks carry it out in credit assessment terms. So that the pattern of implementation of green banking must be sought that can be realized in each credit and financing agreement at the bank so that it can be used with a large awareness and responsibility of all banks in Indonesia. Several green banking patterns must be in place so that the bank has alternative choices about which patterns can be implemented in Indonesia. Another problem is that if the bank has provided credit or financing to the customer, it turns out that the company that receives credit discharges waste into the river or other activities that damage the environment. Do banks provide any financial aids for environmental damage? how was the bank's responsibility for credit channeled to polling debtors?

The bank functions as an intermediary institution, to mobilize funds from the community and redistribute these funds to the people who need them in the form of credit and financing facilities, providing financial services, remittances, opening letters of credit, bank guarantees, and other services.

In Law 10 number 10 of 1998 concerning banking was stated, the Bank as an intermediary institution carried out activities to collect funds from the public in the form of savings, giro, deposits and subsequently redistributed to the community in the form of loans in order to improve the welfare of the community. Conventional banks and Islamic banks in distributing credit and financing to their debtors, besides needing to pay attention to the health principles of the bank, also need to pay attention to the impact of the credit provision on environmental sustainability. Bank credit has a close relationship with environmental management because the debtor who receives credit from the bank will run a business that will more or less dispose of waste resulting in environmental pollution, so that the bank can participate in financing environmental damage through credit and financing.

Banking institutions, in essence, have a strategic role in efforts to protect and manage the environment, Islamic banks can do so through a green banking pattern. Green banking is a financial institution that gives priority to environmental preservation in its business practices. Credit policy and financing in banks that are environmentally sound (green banking) can increase social accountability and give distinctive advantages.

The role of banks must be increased, not only to carry out their functions as a collector of public funds and give them in the form of financing but can do more broadly. Distribution of funds that prioritizes cooperatives, medium-sized enterprises and small businesses and various layers of society without discrimination, so as to strengthen the basis of the national economy without 
ignoring the principle of prudence. The distribution of funds for business activities that are at risk for the environment needs to be improved, for instance by streamlining the AMDAL instruments for large-scale companies or their activities having a major impact on the environment.

The existence of banks in a society that continues to grow increasingly occupies important and strategic positions, as well as in the state financial system, banks are intermediary institutions that connect economic units in all countries. As a public fund collector, banks are appropriate for companies, government institutions, private and individuals to save funds which are then distributed through financing activities and various other financial services. Thus Islamic banks facilitate the system of credit and payments for all economic sectors (Thomas, 1999: 17). Banks are increasingly important in the traffic of payments and business traffic between countries.

For this reason, banks as financial institutions that manage public funds are required to manage their business optimally, both in collecting and distributing it back to the community. The purpose of lending must be able to improve the welfare of community and not vice versa, which actually causes a detrimental impact on the community such as the occurrence of environmental damage carried out by companies funded by bank credit and financing.

In Indonesia, there are no adequate regulations regarding the implementation of green banking, only in Bank Indonesia regulations, namely PBI No 7/3 / DPNP / 2005, 31 st January 2005, which "advocates" for distributing loans that pay attention to the environment. Therefore, Bank Indonesia for the foreseeable future has a regulation that clearly and explicitly states the requirements for environmental maintenance for debtors.

In developing countries, most laws function as a tool for the government to change conditions, achieve certain goals and to establish new habits. So that it can be said that the law as a tool for social engineering in Indonesia is still very much required. Rapid changes make developing countries use the law to balance themselves with developed countries.

Based on the description of the background, it is important to study how the globalization of economic law has implications for the implementation of green banking. It is important to be appointed and enhanced the role of banks in the context of environmental protection and management. Bank loans are closely related to environmental management because debtors who receive credit from banks will certainly run their businesses which will waste more or less waste which will result in environmental damage. 
Based on the background of the problem above, the problems that can be formulated areas How was the bank's social responsibility if credit funds are used by debtors for activities that pollute the environment? And how was a good green banking pattern and in accordance with the regulations and the banking world in Indonesia?

\section{Discussion}

In this era, there were regional, national and international changes. According to Soejono Soekanto, changes in people's lives are all changes that occur in social institutions that affect their social systems. These include values, attitudes and behavioral patterns among groups in society. Its influence is further a change in the order of social life, including political, socio-economic, socio-cultural as well as law and legislation (Soekanto, 1999: 12).

Legal developments in a country including Indonesia cannot be separated from globalization as a process where various events, decisions, and activities in one part of the world can have important consequences for various countries and communities in other parts of the world. This term was originally used to refer to political-economy, particularly the politics of free trade and financial transactions. There are four aspects of globalization that many have raised, those are:

1. All political, social and economic activities across countries.

2. The increased flow of trade, investment, finance, migration, and culture.

3. Information systems, capital, and people/companies move faster.

4. Events that are geographically distant, have an impact on other regions.

The law in Indonesia is cannot be separated from economic globalization. Since economic globalization has actually happened for a long time, during the spice trade, the culture steel and the period in which Dutch colonial private capital with forced labor. In all three periods, Indonesian crops have reached Europe and America. Economic globalization is now being a new manifestation of the capitalist development as an international economic system, such as during the monetary crisis in Indonesia, multinational corporations under the pretext of overcoming the crisis the company sought new markets and maximized profits by exporting capital and reorganizing the production structure. Globalization causes the development of interdependence of world economic actors. Manufacturing, trade, investment cross the national border and increase the 
intensity of competition. This phenomenon is accelerated by the advancement of communication and technology transportation. When the economy becomes integrated, harmonizing the law follows it. The establishment of the WTO (World Trade Organization) has been preceded or followed by the formation of regional economic blocks such as the European community, NAFTA, AFTA, and APEC. There is no contradiction between regionalization and globalization of trade. In contrast, global economic integration requires the creation of new trading blocks. Joining the WTO and regional economic cooperation means developing democratic institutions by updating market mechanisms and functioning the legal system. So that economic globalization has a huge effect on the law. It can be said that economic globalization causes the globalization of law, globalization of law is not only understood as an international agreement between nations, but also an understanding of the legal and cultural traditions between West and East.

Globalization of law, occurs through efforts to standardize the law. Among other things through international agreements. For example, the General Agreement on Tariff and Trade (GATT) includes several provisions that must be met by member countries relating to investment, intellectual property rights, services, and the principles of Non Discrimination, "Most Favored Nation, National Treatment, Transparency, then it becomes the substance of the regulations of member countries.

In the field of international business contracts globalization has long taken place by the way developed countries bring new models of transactions to developing countries which are then accepted by the model, because of their weak bargaining position so it is not surprising that joint ventures, franchise agreements, licensing agreement, agency agreements are almost the same in all countries. The legal counsel of a country easily works on such agreements in other countries.

The equality of legal provisions of various countries can also occur because a country follows a developed country model relating to legal institutions to obtain capital. Limited laws for various countries. From "Civil law, and Common Law" it contains similar substances. Likewise, with capital market regulations, where there are not many different, one and the other because the funds flowing into these markets are no longer true to the time and national boundaries, the demand for transparency is increasingly large, the development of international crime in money laundering and "insider trading" encourage international cooperation.

Efforts to equalize regulations in the labor and environmental fields will continue. Developed countries requested that developing countries improve 
labor conditions and environmental protection, not only based on human rights but also trade competition. Low labor wages and guarantees, as well as loose environmental protection regulations according to developed countries, are "social dumping" which is detrimental to their competitiveness.

Laws affected by globalization will cause developing countries' regulations on investment, trade, services, and other economic fields to approach developed countries (convergence). But there are no guarantees that these regulations provide the same results everywhere. This is due to differences in political, economic and cultural systems. The law is not the same as a horse, people will not call a donkey or zebra a horse, although the shape is the same as a horse, while the law is not so, what is called law depends on the perception of the people.

Friedmann said that the establishment of legal regulations depends on the legal culture of society. The legal culture of society depends on the legal culture of its members who are influenced by their educational background, environment, culture, position or position, even interests. So whether or not the rules from the international world are accepted depends on the people, it turns out that the people in Indonesia do it, this shows the acceptance of the law sociologically.

In dealing with such things, it needs a check and balance in the state. Check and balance can only be achieved with a strong parliament. Independent courts, and community participation through its institutions. The current of globalization also forces the role of third world economic development to be more advanced. Besides that, the natural resources that are owned will play an important role in carrying out economic development, just how the management of human resources owned can manage productive assets that can support the economic development of each country.

The phenomenon of globalization is also the most obvious, how developing countries in the third world will be targeted by the superpower's economic interests. Not to mention the problem of the gap which is increasingly widening between developing countries and poor countries with developed countries with the Transnational Corporation (TNC). Efforts to eradicate poverty (Poverty Alleviation) as stated rhetorically by world banks and the International Monetary Fund (IMF) are in fact only openly deceiving the public (public lies). Why is that? Because in reality the direction and purpose of globalization with the direction of the goal of eradicating poverty is very contradictory, not only contradictory but also fundamentally opposed. The opening of the market as wide as possible in the whole world of various instruments including world 
banks, IMF, MNC, TNC, WTO, and other similar institutions and markets has never considered social aspects including aspects of changes in human resource regulation and its tendency to be only on the poverty eradication agenda. market creation for how to generate profits and profits. The clearest evidence is the liberalization of the financial sector by the IMF and world banks in the 1980s which is now the main cause of the economic crisis, capital flight out of the country, and the rising debt burden and endless financial volatility that bankrupts developing and poor nations only in a matter of days.

Based on the dynamics of globalization that affect the legal field, the roots can be drawn, namely, first globalization is rooted in the globalization of the economy and other fields that place the global state as a market society. Both legal globalization is rooted in a global state that manifests itself in what is called "global responsibility" so that it indicates that globalization of law is more complicated than economic globalization. Globalization of law in terms of global responsibility has placed itself as a tool for the global state.

In a comparative perspective of the legal system, according to Hari Purwadi, it is true that Indonesia is the most excellent legal laboratory in the world, because it cannot be denied that most legal systems in Indonesia are "import" legal systems from the colonial era to the present (Hari, 2000: 225). Therefore, the globalization of law in Indonesia has long happened, but in the past, it only became a legal system that lived and developed in a sovereign country. Globalization of law in the present development actually grows and develops beyond the boundaries of state sovereignty and even if he lives in a country nationally it occurs because of an international agreement. So that it can happen in the future what will be called the "era of comparative law" even though the current movement does not seem too strong. However, the most important thing in this connection is forcing us to explore the globalization of law on one side and the global legal system on the other. Will the global legal system become part of the globalization of law or the globalization of law giving birth to a global legal system? While nationally it is clear how the influence of globalization has spread and permeated the life of Indonesia's national legal system. For now, only a number of legal systems have developed, namely: civil law systems, common law systems, Islamic law, socialist law, and customary law systems.

Therefore, if globalization goes into the public sphere along with the embodiment of globalization, for Indonesia it is not entirely true because long before Indonesia's independence had taken place, the legal system had been imported into Indonesia. So that the discussion of globalization is related to the movement of globalization to other fields, for example, economic globalization 
must be followed by the globalization of law, so actually, legal globalization is behind the globalization of other fields. It can be said, economic globalization is a new manifestation of the development of capitalism as a social-economic system, where the globalization of law continues to take place in different legal systems.

Soetandyo Wigjosoebroto stated that the process of nationalization was not yet finished, but a new process known as the process of globalization had entered the threshold. This is a process that is essentially an economic and sociocultural process rather than a political process which is, in fact, a spirit of nationalism with ideas that do not want to be bargained for realizing national unity under a strong legality, but reality has made those dreams a dream Now, the development of life no longer stops at the development of the process of integration of local communities into national units but continues (Standyo, 2008: 237). This strengthens the globalization of law to become an inevitable one and finally asks us to "amini" that national life everywhere, whether that unites human beings who are considered "old nations" that have emerged in history as explorers and invaders, as well as the nation young who explored and colonized. Now it has been repeated in another form called globalization, but nevertheless, it has been responded optimistically as a progressive process towards new forms (Francis, 2000: 69).

Some parties believe that global society is not a global state, so it is more appropriate to use the term market society or the global economy. This becomes integral to the global society, where the people of the nation are free from the bonds of their national law. In the current development, globalization is developing further towards global responsibility.

For Indonesia itself, the influence of globalization demands an adjustment to the national legal system and confronts Indonesia with various legal issues that must be resolved. According to Bagir Manan, not only concerns the grand design of national law, there are not yet a number of Indonesian legal conditions which show the following:

1. Judging from the legal substance (principles and principles) to date there are various legal systems in force. Negatively, it can be interpreted as legal politics that enforces a legal system such as allowing people to live in traditional legal environments and are limited to entering the legal system needed for a modern association.

2. In terms of form, the applicable legal system still relies on written legal forms. 
3. Departmental centric, regulations are still regarded as the affairs of the department concerned.

4. Many inconsistencies have been encountered in the use of legal principles or theoretical foundations used in drafting legal regulations, etc. (Bagir, 1999: 238).

Such a situation makes the process of adjusting the national legal system as demand for globalization to be a non-light work so that globalization of law is not only a legal adaptation but also will encourage changes in the practice of dispute resolution between parties that are world instruments.

Regardless of how the relationship that surrounds national law and globalization of the law, then the globalization of the law substantially that various agreements and legislation comes from international conventions, private law, and new economic institutions which are then followed by legal practice, thus legal globalization occurs spreading across boundaries country.

The same goes for the business world that cannot escape from banking institutions as an intermediary in payments. Banks as financial institutions which in fact distribute loans to investors can certainly be said to be involved in financing environmental damage through credit distribution. So it's time for banks to realize social responsibility oriented to the implementation of green banking.

In connection with the function of the bank, Law Number 10 of 1998 concerning changes of Law Number 7 of 1992 regarding banking, next is referred to as UUP 1998, in article 3 it is determined that the main function of banking is to collect and distribute public funds. This means that the presence of banks should not merely as a business objective, but there is another broader mission, that is increasing the welfare of the general public.

Therefore, for a bank that wants to distribute credit to debtors, whether it is a debtor in the form of a legal entity or a debtor who is not a legal entity, the bank needs to pay attention to the bank's sanity principles and take notice to the impact of the credit on environmental sustainability.

Bank in Law Number 10 of 1998 is a financial institution that collects public funds and distributes them to the community in order to improve the community welfare. This indicates that banking activities have a greater purpose, community welfare. In channeling funds banks must be able to lead to the achievement of these goals. 
The relation between banks and customers is a contractual agreement as defined in the Civil Code in article 1338 paragraph (1) which states that all agreements made legally have the same power as the law for both parties. This means that the parties are between the bank and the customer have rights and obligations. If it is carefully studied in the Banking Law Number 10 of 1998, there was not explicitly found regarding the legal relationship between the bank and its customers. However, from several provisions it can be sum up that the connection between the bank and the customer is governed by an agreement, this can be seen from the provisions of article 1 point 5 UUP 1998, which stated that deposits are funds entrusted by the community to the bank based on deposit agreements and in the form of demand giro, deposits, certificates of deposit, savings or other similar forms.

In accordance with the above provisions, it can be said that the relationship between the bank and the customer is governed by the agreement law. The referred agreement here is an event where someone promises to someone else or where the two people deal with each other to do a right. The agreement issued a contract between two people who made it (Subekti, 1992: 7).

Next is about agreement legal issues, that the general provisions can be seen in book III of the Civil Code which adheres to an open system in the sense that the treaty law provides the widest possible freedom to the public to enter into agreements as long as they do not violate public order and morality. The articles in the treaty law are optional laws which cause these articles to be excluded if desired by the party making the agreement. They are allowed to make their own provisions which deviate from the articles of the legal agreement (Subekti, 1992: 21).

The principle in agreement law is known as the freedom of contract. This principle is concluded from article 1338 paragraph (1) of the Civil Code which states that all legal agreements are applied as laws for those who make them. While the conditions for the validity of an agreement can be found in article 1320 of the Civil Code, this article is known to adhere to the principle of consensual.

In fact, the problem of the relationship between banks and customers in practice that the bank has made an agreement in the form of a standard form. In the form stated all the requirements that must be met in accordance with the convention of the bank. This is what legal experts call a standard agreement, meaning that the agreement whose contents have been standardized and set forth in the form (Mariam, 2003: 15). This agreement has grown and has been accepted as a reality because it is desired by the circumstances. 
From this fact, the bank can accommodate environmental interests and standardize it as a form. That condition is expected by many parties who are concerned about environmental protection. So that banks can help the government by giving or distributing credit based on environmental conservation which is more popular with the term green banking.

In Indonesia, AMDAL instruments began to be implemented by several banks as one of the essential parts in the analysis of lending and concerning loan documentations. In terms of legislation, it can be seen on Article 8 of Law Number 7 of 1992 as for Banking as amended by Act Number 10 of 1998. Through Bank Indonesia Regulation Number 7 / 2 / PBI / 2005 pertaining to Asset Quality Rating for Commercial Banks and Bank Indonesia Circular Number 7/3 / DPNP dated January 31 st 2005 about Asset Quality Rating for Commercial Banks which regulates the need for public banks to pay attention to the efforts made by debtors in the context of maintaining the environment. These regulations are then supported by Law Number 32 of 2009 in respect of Environmental Protection and Management.

Basically, development with the environment is two different things or contrast. Development requires a better change towards human welfare or also called growth, and one of the most important is the availability of natural resources.

While nature requires the preservation of its functions and limitations in its availability. Besides that the nature of resources is renewable, some are nonrenewable, they can affect environmental sustainability. Renewable sources can be engineered both in quality and quantity, while non-renewable natural resources cannot be changed, which is possible to save only on natural reserves.

Development is a human means to achieve a level of well-being and can only be done, so as to achieve the goal if sufficient natural and environmental resources are available. With development, environmental risks arise, those are threats that make the quality of the environment damaged and its reserves become unsustainable. Then came the concept of sustainable development.

The environmental declaration, both in Stockholm 1972 and in Rio 1992 is the result of an international agreement which was later accommodated in the environmental management policy system in Indonesia. One of the things agreed upon is that Sustainable Development is basically the same as eco-development, meaning development without sacrificing environmental interests or always paying attention to environmental aspects (principles 1 and 2 of the Stockholm declaration). Laws and regulations concerning environmental management 
which were subsequently published since 1982 were updated in 1997 and then the latest Law Number 32 of 2009 concerning PPLH, sustainable development is called as an effort to achieve prosperity without sacrificing the ability of future generations to get prosperity, so that the environment is utilized not only for the present but still considers the principle of justice between generations.

JohnRawls, states that justice is fairness, where the need for justice is formalized through the constitution and or law as the basis for implementing the rights and obligations of each individual in social interaction. Such formal justice demands minimum equality for all people. Injustice, it requires three moral demands, firstly freedom to determine the freedom of self-determination, as well as independence to other parties. Second, the importance of fair distribution to all opportunities, roles, positions, and benefits or social values found in society. Third, the demand for the distribution of freedom and obligations fairly (John, 1999: 95).

Many progress has been achieved, but only measured by economic growth indicators, while ecologically it experiences a setback marked by environmental damage due to pollution of industrial waste, excessive use of forest products, exploitation of mineral resources and so on.

Even so, criticism of the sustainable development term is expressed in connection with several different interpretations. The developmentalism party highlights sustainable development as the answer to a pattern of trends that prioritizes development in all things, which then becomes a separate understanding to solve all factors of backwardness, commonly called developmentalism. The notion sees the economic side as the most important pillar of everything, so the more patterns of production and consumption increase, the material aspect becomes the main goal of the development process. The impact of the excessively two-sided economic development paradigm, firstly the social, cultural, spiritual and aesthetic aspects are no longer important, even in many ways they are often reduced so as not to become obstacles to development. Second, the materialism aspect of development makes nature and all resources in nature the main object of achieving prosperity or economic growth (Siahaan, 2008: 12).

In Law Number 32 of 2009, it is stated that protection and management of the environment is a systematic and integrated effort carried out to preserve environmental functions and prevent pollution and/or environmental damage including planning, utilization, control, maintenance, supervision, and law enforcement. 
A good and healthy environment is one form of human rights that is consistent with Article $28 \mathrm{H}$ of Indonesian's Constitutional of 1945. Thus development must be a conscious planned effort that integrates environmental, social and economic aspects in development strategies to ensure the integrity of the environment and safety, ability, welfare and quality of life of present and future generations.

It has to be realized that the environment quality in Indonesia has decreased in quality. In addition, increasing global warming resulting in climate change exacerbates the decline in environmental quality. On the other hand, the spirit of regional autonomy has brought about changes in the relationship between the authority of the central government and regional governments, including the protection and management of the environment. Article 42 of Law Number 32 of 2009 it has been determined that regional governments must develop and implement environmental economic instruments in the form of development planning and economic activities, environmental funding, incentives, and disincentives.

The majority of the articles contained in Law still showed the principle of state responsibility for environmental management, community participation is still little regulated so that public awareness must continue to be developed. The magnitude of state responsibility is very visible in pollution prevention instruments, including spatial planning, environmental quality standards, criteria for quality standards for environmental damage, AMDAL, licensing, economic instruments, environment-based budgets, environment-based legislation, and others.

In this regard, a model for developing responsive legal thinking has been introduced by Philippe Nonet and Philip Selznick. This can be seen in responsive legal construction based on two legal schools that are legal realism and sociological jurisprudence. Because if the political configuration is a democracy, it will give birth to a responsive legal character. Configuring full people's participation to actively determine public policy, this participation can be fixed on the basis of a majority by people's representatives in periodic elections based on the principle of political equality and organized in the atmosphere of political freedom.

In the Law Number 32 of 2009 concerning PPLH, it is possible to use environmental economic instruments which are interpreted as a set of economic policies to encourage the government, regional government or everyone towards the preservation of environmental functions. Encourage financial institutions to become environmentally friendly financial institutions so that they can create a 
system of financial institutions that apply environmental protection and management requirements in financing policies and systems practices of financial institutions of banks and non-bank financial institutions. Furthermore, it is expected to create an environmentally friendly capital market, so that it can implement environmental protection and management requirements for companies entering the capital market or public companies such as the application of environmental audit requirements for companies that will sell their shares in the capital market.

In tone with this, the law is used as a social engineering tool, so it can still be used to form the desired state in accordance with the objectives of the law. Changing a habit, in this case, is the habit of banks in giving credit. Thus, Environmental Law here contains benefits as a regulator of human interaction with the environment in order to achieve social order. In accordance with its purpose, which is not merely an instrument of order, environmental law contains goals for social engineering. In this discussion, social engineering is very important, with the content that the community in its interaction with the environment can be directed to receive and respond to the principles of development, for example, banks will make AMDAL as a requirement to apply for credit for activities that affect the environment. Thus the rules have values or principles that encourage renewal in the behavior of banks in lending.

Legal theory as a tool for engineering is a theory proposed by Pragmatic Roscoe Pound, which is legal realism, as follows:

a. Law as a tool of social engineering.

b. Law encourages reform from traditional to modern.

c. The trick: launch social relations in the community, create peace, order, and justice for all people.

d. Manifested in the form of Law, legislation, and jurisprudence

e. Laws that live in society, are characterized by their functions that effectively regulate roles and behaviors and protect the interests of community members (RB. Sumanto, 2013: lecture materials).

Banks as intermediary institutions carry out activities to raise funds from the public in the form of savings, current accounts, and deposits, and subsequently redistribute to the community in the form of loans in order to improve people's welfare. Banks in channeling credit to their debtors, besides needing to pay attention to the health principles of the bank, also need to take one to the impact of the credit provision on environmental sustainability. Bank 
loans have a close relationship with environmental management because the debtor who receives credit from the bank will run the business which will waste more or less waste which results in environmental pollution, so that the bank can participate in financing the occurrence of environmental damage through lending.

However, banking institutions have a strategic role in efforts to protect and manage the environment. Banks can do this through a green banking pattern. Green banking is a financial institution that gives priority to environmental preservation in its business practices. Credit policies at banks that are environmentally sound (green banking) can increase social accountability and give distinctive advantages.

Internationally banks that have been able to implement an environmentally friendly credit distribution system are referred to as green banking, which in Indonesia means that it applies to Conventional Commercial Banks and Banks with Sharia principles.

In addition to conventional banks, Islamic banks have different objectives than conventional banks, Islamic banks stand to promote, maintain and develop banking services and products based on Islamic sharia. Islamic banks also have an obligation to support the running of investment and business activities, as long as the activity is not prohibited in Islam. The main principles of Islamic banks consist of the prohibition on usury on all types of transactions, the implementation of business activities on the basis of equality, fairness and transparency, the formation of mutually beneficial partnerships and of course the benefits that can be obtained from business with Halal ways (Tim, 2001: 23).

Nevertheless, just like other business entities, banks are certainly expected to be able to generate profits in their operations, so that in addition to these objectives the bank must be able to harmonize profit goals with aspects of Islamic morality that underlie all operations.

The function of the bank in environmental management should be expanded. In carrying out its business, the bank is obliged to pay attention to environmental aspects in its agreements with customers, considering that currently, the environment is an inseparable part of the world of global business and interference from other countries in the form of international agreements.

Banks that have the main function of collecting public funds and then redistributing them to the community in the form of credit as referred to in UUP 1998, so that Islamic banks should incorporate aspects of environmental management into financing agreements agreed with their customers. In Law 
Number 10 of 1998, there is no single article that explicitly regulates the obligation for banks to include provisions for environmental management. But implicitly from the provisions of article 4 which stipulates that Indonesian banking aims to support the implementation of national development in order to improve equity, economic growth and national stability towards increasing the welfare of the people.

Based on the terms of the article, an interpretation can be made that Islamic banks in distributing financing to borrowing customers should have the bank includes the obligation requirements for customers who do not accept these conditions, then the financing agreement is automatically canceled.

Given the relationship between banks and customers is a contractual relationship, the bank has an important role in environmental management through financing channeled to borrowing customers, both individuals and legal entities. If it turns out that the funding is received by a company that disposes of pollutant waste, the bank can be said to be a bank to finance environmental destruction, so Islamic banks are responsible for environmental damage, because seen from the relationship between the bank and the customer as stated in the financing agreement, the bank has authority to arranging all credit requirements contained in the credit application form prepared by the bank. Starting from the description, Islamic banks can be burdened with responsibility for environmental damage done by customers.

The bank has the obligation to supervise financing disbursed to debtor customers and if there is a deviation in the use of financing funds or a loss to the community for the business carried out by debtor customers through received funding funds, the bank and the customer have the obligation to jointly take environmental recovery measures life, so that the bank's goal to raise public funds and channel them to the community to improve people's welfare will be realized.

This obligation is actually an embodiment of Article 65 of Law Number 32 the Year 2009, namely that everyone has the right to a good environment as a form of protection of Human Rights. In addition, everyone can play a role in environmental protection and management, while everyone is obliged to maintain environmental preservation.

Environmental-oriented development can be successful if done together, the government makes policies that are in line with every sector of the economy. Bank Indonesia as a central bank is very important to issue policies that favor environmental preservation. The policy issued by BI will encourage the banking 
sector in Indonesia to immediately implement the green banking pattern on credit disbursement agreements for business activities that have an impact on the environment.

The AMDAL instrument is one of the important things for the financing filing document as a condition for disbursing financing, this can be a preventive effort in environmental conservation. Nevertheless, there need to be adequate incentives from bank Indonesia for commercial banks that have implemented the green banking pattern. So according to the author, the implementation of green banking needs to be helped smoothly with some of the patterns most likely to be carried out by Islamic banks and can be agreed upon by debtor customers. In Indonesia, AMDAL instruments began to be implemented by several banks as one of the important parts in the analysis of lending and concerning credit documentations. In terms of legislation, can be seen in Article 8 of Act Number 7 of 1992 about Banking as amended by Act Number 10 of 1998. Through Bank Indonesia Regulation Number 7 / 2 / PBI / 2005 pertaining to Asset Quality Rating for Commercial Banks and Bank Indonesia Circular Number 7/3 / DPNP dated January 31 $31^{\text {st }}, 2005$ in respect of Asset Quality Rating for Commercial Banks which, among other things, regulates the need for public banks to pay attention to the efforts made by debtors in the context of maintaining the environment. These regulations, then supported by Law Number 32 of 2009 as for Environmental Protection and Management.

From the observations, it was found, that the AMDAL instrument had not been used effectively only just the fulfillment of credit application requirements, the policies that led to existing green banking, had not been carried out by the majority of banks in lending. So it is important to look for policy patterns that are an alternative to implementing green banking.

Then the authors propose recommendations for green banking patterns as follows: 1) Administrative pattern: AMDAL instruments are made as an absolute requirement for credit applications for business activities that are environmentally risky 2) Associative Patterns: joint policies made by Bank Indonesia and the Ministry of Environment with a focus on functions supervision. 3). Incentive Pattern: BI provides incentives (for example: including them in the assessment of bank soundness) for commercial banks that carry out environmentally sound credit policies. 4) Evaluative Pattern: The Bank and Bapedal monitor the implementation of the AMDAL, the results of which will be used for credit sustainability.

In this case, it is very important for the participation of banks as active subjects who are aware of and involve themselves in the authentic development 
process. So that there will be a harmonization between state responsibility and bank participation. If viewed from the side of corporate social responsibility, the corporation with banking activities should also have the obligation to carry out social responsibility for the community and the environment so that a harmonious relationship between the bank and the environment, values, norms of justice will be created.

The bank's social responsibility has a reciprocal dimension, the bank is committed to sustainable development, improving the quality of economic capabilities and at the same time increasing people's welfare. Banks that carry out social responsibility in the form of implementing green banking will obtain indirect benefits, namely improving the quality and sustainability of natural resources which can be a staple and support for the sustainability of bank lending.

This responsibility needs to be borne by the bank because in fac, banks participate in financing companies that are engaged in managing natural resources which have an impact on the quality of these resources. For comparison, in Law Number 25 of 2007 concerning Investment, the imposition of corporate social responsibility on companies is extensive, because all types of investments, both those that manage and those related to natural resources and outside those activities are obliged to carry out corporate social responsibility not limited to a certain form of company. Because according to the Investment Law the social responsibility obligation is borne by every form of company that makes investments, whether legal or non-legal entities, including individual businesses. The bank fulfills the above understanding.

The implementation of the green banking pattern is an extension of the company's legal responsibilities to anticipate global environmental issues. So that it should be imperative (mamaksa), not just philanthropic as it is now as if for charitable actions for the environment.

The implementation of green banking is not only a recent "trend", but it is an important thing that must be done in order to be able to manage the environment in an integrated manner that is combining various elements or synergizing several related elements. So in it is not only the government but the effectiveness of the implementation of green banking is the integration in the management, preservation, and control of the environment. 


\section{Conclusion}

Banks are institutions that can encourage economic development by passing financial aids for business activities. Banks can play a role in protecting and managing the environment by implementing a green banking pattern in terms of financing distribution.

Bank Indonesia as the central bank has to make the vivid and clear regulations so that commercial banks can carry out a lending with green banking pattern. By using top-down regulations, it is expected that the practice of green banking can be accelerated, since the environmental conditions in Indonesia are very critical and it is worried that within ten years it will unable to espouse development towards prosperity.

The result of observation was found that the AMDAL instrument had not been used effectively, yet it was only just the fulfillment of credit application requirements, the policies that led to the existence of green banking had not been carried out by the majority of banks in lending. Hence, it is important to look for policy patterns as an alternative to implementing green banking.

Build upon the research conducted, the authors propose recommendations for green banking patterns that can be done in Indonesia as follows:

1) Administrative pattern: AMDAL instruments are used as an absolute requirement for credit applications towards business activities that will give risk on the environment

2) Associative Patterns: the joint policies made by Bank Indonesia and the Ministry of Environment with a focus on the supervisory function.

3) Incentive Pattern: BI provides incentives (for instance: bringing them in the assessment of bank soundness) for commercial banks that carry out environmentally sound credit policies.

4) Evaluative Pattern: The Bank and Bapedal monitor the implementation of the AMDAL, the results of which will be used for credit sustainability.

The results of this paper are practical for the reader as a new insight into the real world of banking, not only as a financial institution that collects public fund but also can take a broader role in participating preventive actions so that there is no "lasting" pollution. In addition, the community as a customer must have the awareness to choose a bank that has implemented green banking. 


\section{References}

Badruzaman, M.D. Perjanjian Kredit Bank, Bandung: Alumni, 1993.

Fukuyama, F. The Great Disruption: Human Nature and The Reconstitution of Social Order, London: Profile Books, 2000.

Rawls, J. A theory of Justice (Revised edition), The President and Fellowship of Harvard University Press, Cambridge, Massachusetts, 1999.

Manan, A. Aspek-aspek Pengubah Hukum, Jakarta, Prenada Media, 2005.

Manan, A. Hukum Ekonomi Syariah, Jakarta: Kencana, 2012.

Manan, B. Pembinaan Hukum Nasional (dalam Mochtar Kusuma Atmadja, Pendidik dan Negarawan, Kumpulan Karya Tulis Menghormati 70 tahun Prof. Dr. Mochtar Kusuma Atmadja, SH. LL.M.) Bandung, Alumni, 1999.

Purwadi, H. Pendekatan Baru dalam Studi Perbandingan Hukum : Critical Comparative Law dan Transplantasi Hukum di Indonesia dalam Wajah Hukum di Era Reformasi, Bandung: Penerbit PT Citra Aditya Bakti, 2000.

Radjagukguk, E. Peranan Hukum dalam Pembangunan pada Era Globalisasi, Jurnal Hukum, No. II Vol 6.

Raharjo, S. Keluasan Reformasi Hukum, Kompas, 8 Mei 1998.

Salim, E. Pembangunan Berkelanjutan, Jakarta: Gramedia, 1997.

Siahaan, N.H.T. Hukum Lingkungan, Jakarta: Pancuran Alam, 2008.

Sjahdaeni, S.R. Aspek Hukum Perbankan, Jakarta: Rajawali Press, 2000.

Soekanto, S. Pokok-pokok Sosiologi Hukum, Jakarta, Raja Grafindo Persada, 1999,

Soemanto, R.B. Perkuliahan S 3 Ilmu Hukum.

Subekti, R. Hukum Perikatan, Jakarta: Intermasa, 1992.

Suyatno, T. Kelembagaan Perbankan, Jakarta: Perbanas, 1999.

Tamin, B.Y. Kutipan dari Thimothy Lindsey and Veronica Taylor, Rethinking Indonesian Insovency Reform, Ausaid, Desert Pea Press, 2000.

Tim Pengembangan Perbankan Syariah, Institut Bankir Indonesia, Konsep, Produk dan Implementasi Operasional Bank Syariah, Jakarta: Djambatan, 2001.

Wigjosoebroto, S. Pluralisme Hukum dalam kehidupan Global, Hukum dalam Masyarakat, perkembangan dan masalah, Bayu Media, Malang, 2008. 
Ria Safitri, Hartiwiningsih, Hari Purwadi

\section{Legislation}

Kitab Undang-undang Hukum Perdata

UU No. 101998 tentang Perubahan Atas Undang-undang No. 7 tahun 1992 tentang Perbankan.

UU No. 10 tahun 1998 tentang Perbankan

UU No. 25 tahun 2007 tentang Penanaman Modal

UU No. 32 tahun 2009 tentang Perlindungan dan Pengelolaan Lingkungan Hidup. 
in Collaboration with :

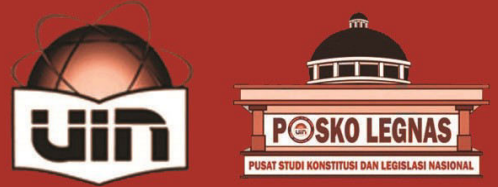

Indexed by :
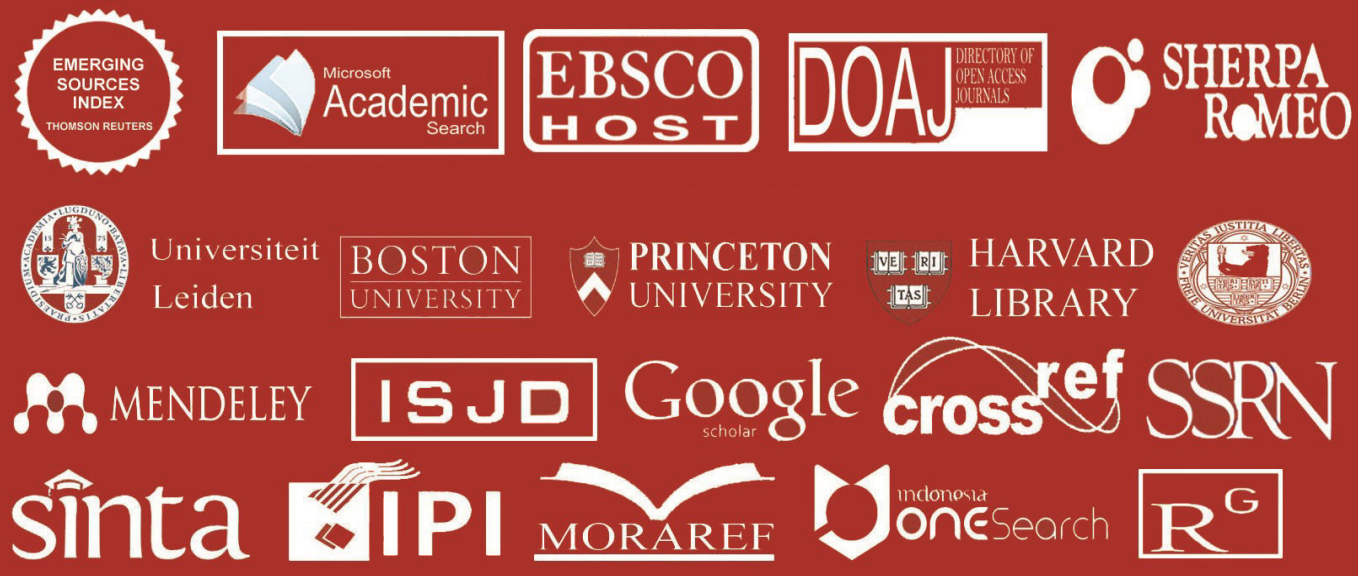

JURNAL CITA HUKUM is a peer-reviewed journal on Indonesian Law Studies published biannual (June \& December) by Faculty of Sharia and Law Universitas Islam Negeri Syarif Hidayatullah Jakarta in cooperation with Center for the Study of Constitution and National Legislation (POSKO-LEGNAS). JURNAL CITA HUKUM aims primarily to facilitate scholarly and professional discussions over current developments on legal issues in Indonesia as well as to publish innovative legal researches concerning Indonesian laws.
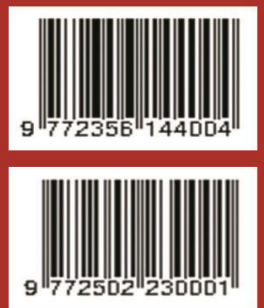